\title{
Indonesian Navy Against Covid-19
}

\author{
Suhirwan* \\ Fakultas Strategi Pertahanan, Universitas Pertahanan \\ Kompleks IPSC, Sentul, Sukahati, Kec. Citereup-Bogor, Jawa Barat-Indonesia (16810) \\ Lukman Yudho Prakoso \\ Fakultas Strategi Pertahanan, Universitas Pertahanan \\ Kompleks IPSC, Sentul, Sukahati, Kec. Citereup-Bogor, Jawa Barat-Indonesia (16810) \\ Andryan Ole \\ Fakultas Strategi Pertahanan, Universitas Pertahanan \\ Kompleks IPSC, Sentul, Sukahati, Kec. Citereup-Bogor, Jawa Barat-Indonesia (16810) \\ Cecep Kurniawan \\ Fakultas Strategi Pertahanan, Universitas Pertahanan \\ Kompleks IPSC, Sentul, Sukahati, Kec. Citereup-Bogor, Jawa Barat-Indonesia (16810)
}

\begin{abstract}
The end of 2019 began the beginning of 2020, starting with the Wuhan-China Virus Covid-19 to rapidly attack various countries around the world. Indonesia has become one of the countries that is not entitled to use the dangerous virus Covid-19, government work together in overcoming this epidemic virus, include the Navy. Indonesian Navy was directly involved as one of the main entities in the quarantine process by involving its medical personnel and Indonesian Warship (KRI) dr. Soeharso. This paper will discuss the role of the Indonesian Navy in overcoming the covid-19 plague virus pandemic with the aim of the Navy to further enhance its role in national defense to try to educate. The method in this article uses descriptive qualitative research and theory analysis of George C. Edward III policy implementation. The results: Communication factors to improve the transmission sub factors, clarity and consistency in mitigating the education. Resource factor is finding for medical personnel due to the limited need for urgent support equipment. Disposition factor considering the ability of the Navy that has a quick and responsive response. Bureaucratic structure factor is need for SOPs to be provided again is sought for the structure of the Navy in urging educators, handled by the Indonesian Navy's "Puspek Nubika" can support its role in helping the eradication of educators nationally. There is still a need to extend the Navy's preparedness to face the challenges of educators so that the Navy can be more useful in tackling the pandemic nationally.
\end{abstract}

Keywords: Covid-19, George C. Edward, Indonesian, Navy, Pandemic.

DOI: $10.7176 / \mathrm{PPAR} / 10-5-02$

Publication date:May $31^{\text {st }} 2020$

\section{Introduction}

The World Health Organization (WHO) on January 12, 2020 (Suganthan, 2019) stated that new cases of viral pneumonia occurred in Wuhan, Hubei Province; and later called "2019 Coronavirus Novel (2019-n-CoV), until now, the new corona virus pandemic (COVID-19) still triggers fears of people around the world. caused globally, viruses known to attack the respiratory system have infected more According to Rothan and Byvydy, Coronavirus (COVID-19) is caused by SARS-COV2 and represents a potentially fatal disease-causing agent that is a major global public health problem, according to a large number of infected people exposed to the wet animal market in Wuhan City, China, it is suggested that this is likely the origin of the COVID-19 zoonosis (Rothan \& Byvydy, 2020). Quoted from the World Meters page, as of Monday morning, April 6, 2020, the total number reached 1,269,299 cases, with 69,346 of them died and 261,200 have been declared cured (Pikiranrakyat.com, 2020).

The Indonesian nation is experiencing the Covid-19 Pandemic National Disaster. In 33 days after the announcement there was a very rapid increase from 2 to 1986 cases with the death of 181 people or $9.1 \%$. Deaths in our country are higher than the global average of $5 \%$ or 58,773 deaths from $1,094,068$ cases. This condition is a serious and worrying threat for all Indonesian people who impact on various aspects of life (Detik.com, 2020). This disaster is not just a health problem, even though it originates from a health problem, but it is very complex regarding social, economic, political, defense and security issues. If this condition is considered a battleground in the face of disaster, doctors and health workers are soldiers who must be at the forefront.

But it is not enough just to rely on doctors and health workers in the fight against this Covid-19 disaster. Also not only ask the government to be responsible for overcoming this disaster with various policies and efforts that have been made to overcome this disaster. Massive movements of all components of the nation are needed at this time. 
The government must look at the Corona virus pandemic (COVID-19) in terms of national defense. So, the government does not only see COVID-19 from a health perspective, so we can put the Corona virus outbreak as a non-military threat. The Indonesian government should no longer handle the COVID-19 pandemic partially, but it must be with a comprehensive policy.

The outbreak of the corona virus can be a serious threat to Indonesia in terms of defense and security. The government as the holder of state control must be able to prepare themselves as well as possible to anticipate the various possibilities and potential of the collapse of national defense. at this time anticipatory steps are needed. Included in efforts to strengthen the Indonesian Arm Forces (TNI) in developing strategies or the ability to defend against any weapon attack.

The government must be able to anticipate and strengthen our TNI in order to face the CBRNE (Chemical, Biological, Radiological and Nuclear Defense) war if it is really needed, Indonesia needs to implement a special protocol, for example by isolating the region and imposing martial law on disaster in all regions transmission of the virus is difficult to suppress. All done to anticipate the increasingly widespread spread of the virus.

At present every TNI Services has units prepared to deal with special war threats such as the threat of Nuclear war, Biology and Chemistry (Nubika), in the ranks of the Indonesian Navy (TNI AL), all soldiers are given a briefing in dealing with the Nubika war, Nubika training is held at the Puspek Nubika Kodiklatal's in Surabaya. TNI human resources already have a good stock in facing the Corona Pandemic as it is today, so it becomes interesting for the writer to make an analysis of how the Navy can be optimized for the national interest in dealing with the current pandemic conditions, it is hoped that this paper can be useful for the interests of the nation and the current and future countries.

\section{Methods and Theories}

This study uses qualitative methods, according to, the notion of qualitative research is research based on the philosophy of post positivism, used to examine natural conditions of objects, (as opposed to experiments) where the researcher is a key instrument, sampling data sources is done purposively and snowball, triangulation (combined) collection techniques, data analysis is inductive or qualitative, and qualitative research results emphasize more on meaning than generalization (Sugiyono, 2009).

According to Polkinghorne (Creswell \& Poth, 2007), Phenomenology studies illustrate the meaning of a life experience for some people about a concept or phenomenon. People involved in dealing with a phenomenon explore the awareness structure of human life experiences. Meanwhile, according to Husserl (Creswell \& Poth, 2013) phenomenological researchers try to look for things that are necessary (essential), invariant structure (essence) or the meaning of experience that is fundamental and emphasizes the intensity of consciousness where experience consists of things that appear from the outside and things that are in each consciousness based on memory, image and meaning.

The theory used to analyze the problem is according to George C. Edward III which states that the factors that influence the success of policy implementation are four factors or variables of the policy namely bureaucratic structure, resources, communication, disposition (Edward III, 1980).

\section{Analysis and Discussion}

The World Health Organization (WHO) finally officially declared the corona virus outbreak or Covid-19 disease as a pandemic, last Wednesday (11/3/2020), or more than two months since the outbreak began to be detected in China (BeritaSatu.com, 2020)

Apart from the long period of time, the pandemic status has nothing to do with changes in the characteristics of the disease, for example, a disease that is more virulent than before.

Pandemics are more related to the geographical distribution. Simply put, the meaning of a pandemic is an outbreak of a new disease that spreads in various countries at the same time. According to WHO, the status of a pandemic is determined if a new disease that does not yet have an antidote to immunity spreads to various regions of the world unexpectedly.

In Law No. 34 of 2004 mentioned that the main tasks of the TNI in principle there are three, namely; first, upholding the country's sovereignty; secondly, maintaining territorial integrity and thirdly, protecting the entire nation and all Indonesian spills from threats and disruption. These main tasks are carried out through Military Operations for War (OMP) and Military Operations Other Than War (OMSP) (Indonesian Law NO 34 of 2004, 2004).

In the OMSP, which has 14 task details, namely to overcome armed separatist movements, overcome armed uprisings, overcome acts of terrorism, secure border areas, secure national vital objects that are strategic, carry out world peace tasks in accordance with foreign policy, secure the President and the Vice President and his family, empower the defense area and its supporting forces early in accordance with the universal defense system, assist the tasks of government in the area, assist the Republic of Indonesia National Police in the framework of security and order, the people regulated in the law, help secure state guests equivalent to the head of state and 
representatives of foreign governments who are in Indonesia, helping to cope with the effects of natural disasters, refugees, and providing humanitarian assistance, assisting in the search and rescue in an accident (search and rescue), assisting the government in safeguarding shipping and flight against piracy, piracy and smuggling

Faced with the problem of how to optimize the involvement of the Navy in handling Pandemics, children are first analyzed how the current implementation of the Navy's involvement, then from the results of the analysis it is hoped that solutions can be found so that the involvement of the Navy can be more optimal in handling the Pandemic 19 pandemic, the following is analysis of the implementation of the involvement of the Navy in handling pandemics:

\subsection{Implementation of the involvement of the Navy in dealing with Pandemics}

3.1.1. Communication

One element that can influence the successful implementation of a policy according to George C. Edward in Nugroho is communication (Nugroho, 2011). Distribution of good communication will be able to produce a good implementation as well. Problems often occur in the distribution of communication namely the misunderstanding (miscommunication) caused by the many levels of bureaucracy that must be passed in the communication process, so that what is expected to be distorted in the middle of the road (Suhirwan \& Prakoso, 2019).

The existing communication network in the Navy will appear in every organizational unit in the Navy. This communication net is arranged to be Top Down and Bottom Up, meaning that orders will come from superiors and input suggestions and implementation reports come from subordinates to their superiors. The Indonesian Navy is part of the TNI structure that has a fixed command net to carry out the battle, so it is very suitable for use in handling the Covid-19 pandemic. Communication can be established quickly, effectively and efficiently. With the existing system within the TNI which is commanding, the clarity, transmission and consistency of communication in handling the Covid-19 pandemic seems clear who is doing what and how the resolution mechanism is.

3.1.2. Resources.

Resources are an important factor for the implementation of policies properly, so it is necessary to have sufficient human resources (HR) and to increase the skills (capabilities) possessed by the implementers of the policy itself, according to George C. Edward III in Nugroho. The resources here are divided into two, namely in the form of human resources (staff) and non-human resources (facilities or infrastructure) (Nugroho, 2011).

a) Staff.

The main resource in implementing policies is staff or employees (street-level bureaucrats). Failures that often occur in policy implementation, one of which is caused by staff / employees who are inadequate, insufficient, or incompetent in their fields (Suhirwan \& Prakoso, 2019). The quality of human resources related to skills, dedication, professionalism, and competence in their fields, while the quantity related to the amount of human resources is enough to cover the entire target group.

TNI and Navy personnel already had basic resources for a special Nubika war. Provision of the ability of both the theory and practice of handling Nuclear Biology Chemistry has been studied by Navy personnel so that the professional quality of Indonesian Navy soldiers has been trained. The handling of this pandemic is very appropriate if it involves Navy soldiers to deal with the Pandemic Covid-19. Navy personnel who are physically trained and their stamina have the speed needed to prevent more casualties.

b) Facilities and infrastructure.

In addition to the ability of qualified human resources, the facilities and infrastructure are also very necessary for handling this Covid-19 pandemic. Non-human resources include adequate funds, availability of facilities and infrastructure. According to Edward III in Agustino, non-human resources are an important factor in policy implementation (Agustino, 2008).

Facilities are an indispensable factor in implementing a policy. To help deal with the Covid-19 pandemic, the Indonesian Navy has infrastructure in the form of equipment that supports the handling of the pandemic, so that the government only needs to complete the necessary equipment. The Navy's resources are structured in all regions of Indonesia so that this becomes an effective and efficient factor in handling pandemics.

3.1.3. Disposition.

One factor that has important logical consequences for effective and efficient policy implementation is the disposition of the implementer or policy implementer (in this case the disposition of the Navy) under the leadership (in this case the President of the Republic of Indonesia) as a policy maker in dealing with the Covid-19 pandemic in Indonesia. If the implementers have a positive tendency or attitude or support for the implementation of the policy, there is a high possibility that the policy implementation will be carried out in accordance with the initial decision (Suhirwan et al., 2020). Article 7 of Law number 34 of 2004 has regulated the main tasks of the TNI / TNI AL in terms of their main duties to carry out Military Operations for War (OMP) and Military Operations Other Than War (OMP). The involvement of the Navy in the handling of the Covid-19 pandemic is one of the main tasks of the OMSP category as listed in point 12, which is to help overcome the consequences of natural disasters, refugees, and the provision of humanitarian assistance. 
The role of the Navy as one of the main components of national defense in implementing the OMSP in general and the handling of the Covid-19 pandemic in particular is inevitable and must instead be put forward. The main character of the Navy that is loyal and impartial is politically practical, and is supported by resources and defense equipment that are relatively complete both at sea, air, and land and coupled with the experience of Navy Marines in carrying out security and reducing riots that occurred in many areas, especially in the capital city of Jakarta, are a factor of strength or strength possessed by the state to not only be a guardian of Indonesia's sovereignty and wholeness, but also to be a state tool in overcoming the Covid-19 pandemic. Without understating the role of the Indonesian Army (TNI AD) and the Indonesian Air Force (TNI AU) in carrying out their role in the OMSP, the Navy is a prepared dimension and has been proven capable of carrying out OMSP activities, such as reducing many riots and maintaining harmony the nation's children under the umbrella of Pancasila and Unity in Diversity, carry out Humanitarian Assistance and Disaster Relief (HADR) on many natural disasters; tsunami, earthquake, volcano eruption, and others.

The involvement of the Navy in the Covid-19 global pandemic has also been done very well through pickup, evacuation, quarantine and repatriation of Indonesian citizens from many countries who declared the emergence of the Covid-19 pandemic. From its position as a state instrument in the military-oriented defense field, the Navy can quickly transform itself to implement the OMSP according to the instructions and / or policies of the President of the Republic of Indonesia as the Head of State and Head of Government.

3.1.4. Bureaucratic Structure.

Implementation of complex policies requires the cooperation of many parties. When the bureaucratic structure is not conducive to the implementation of a policy, this will cause ineffectiveness and hinder the implementation of the policy (Suhirwan et al., 2020).

An effective and efficient bureaucratic structure, which can reach all corners of the country, is a determining factor for the success of the implementation of the policies that have been made. The Indonesian Navy has a bureaucratic structure that is spread all over Indonesia. This is a strategic factor that makes the Navy's existence very vital in dealing with and overcoming the Covid-19 pandemic. Like military organizations in general in the world, the Navy's organizational structure that is in line with structural and coordinating commands is a bureaucratic structure factor in the implementation of public policies that can be quickly operated. This is due to the unity of the command system which has been maintained for a long period of time and is continuously being evaluated and corrected for its shortcomings by the Navy.

In factual implementation, the Navy can deploy all of its resources, especially the KRI, quickly. In addition, with a good command bureaucratic structure, the Navy has been able to anticipate orders or policies that are very likely to be made by the President of Indonesia as a policy maker. An example is the preparation of the KRI Hospital Ship Dr. Suharso-990 which was used for picking up 74 Indonesian citizens who were the daughter of the Diamond Princess in Japan. The preparation of the KRI was carried out, without orders from policy makers, because the Indonesian Navy analyzed the possibility of many alternatives to be made by the President of the Republic of Indonesia so that he could quickly anticipate decisions to be issued. In other words, the Indonesian Navy has a capable bureaucratic structure that is ready and empowered at all times and as soon as possible to be empowered by policy makers in the interests of the nation and the state in general and in overcoming the Covid19 pandemic in particular.

\section{Optimization of Navy Involvement in facing Pandemic}

4.1. Empowering the Strength of the Indonesian Navy/TNI AL.

The Indonesian Navy has both human and non-human resources (facilities and infrastructure) that can be used to overcome Covid-19 victims. One of the Navy's human resources is the Navy's medical personnel. These medical personnel have been educated militarily both for combat and health sciences. These medical personnel are trained and equipped with theory and practice in Puspek Nubika Kodiklatal's in Surabaya. Armed ability possessed by the Navy's medical personnel is very qualified for handling Covid-19 victims.

Non-human resources owned by the TNI to support the handling of Covid-19 are very complete, starting from the Biological and Chemical Nuclear Decontamination Room, defense equipment, vacant land and Educational Dormitory buildings.

As one of the functions that can be used from the utilization of biological and chemical nuclear radiation decontamination space that is owned by Puspek Nubika Kodiklatal's in Surabaya is as a means of inspection laboratories for victims and medical personnel exposed to Covid-19.

Use of TNI AL military facilities such as the mashailling area Boarding houses at the TNI AL Education institution can be used as field hospitals or emergency hospitals if there are not enough hospital facilities to accommodate Covid-19 victims.

The Indonesian Navy Armed Forces, namely a number of Indonesian Warships (KRI) types of Transport Tanks and personnel or Landing Ship Tanks (LST) are used as emergency hospitals, and are even able to be used as quarantine for people exposed to Covid-19. The use of this Navy Ship was also carried out by the US when 
sending the Navy hospital ships USNS Mercy (T-AH-19) to California and USNS Comport (T-AH-20) to New York as an Emergency Hospital to provide medical support to Americans in regions significantly affected by the Covid-19 virus pandemic (Navylive, May 8, 2020).

\subsection{Building a multilevel Command Center continues.}

Seeing the problems that occur today, that Covid-19 is a virus whose spread is very massive throughout the world until April 2020, 200 countries have experienced the Covid-19 epidemic. Covid-19 has caused more than 1 million fatalities (Kompas.com, 2020) so there are indications that Covid-19 is a virus created as a biological weapon. The handling of the Covid-19 pandemic must be done together. It is not only the duty of the government but the involvement of all elements of Indonesian society is needed. Public awareness is needed in deciding the spread of Covid-19.

The researcher provides the prerequisite that a Command Center is needed in the handling of the Covid-19 pandemic. Puspek Nubika as an Educational Institution that is in the Navy's Education and Training Command can be made as by placing one entity as a Command Center. This can only be implemented if the system being built is strengthened with other policies. Which places the Command Center entity as the only one that can issue policies related to the expected interests in law enforcement at sea to deal with drug smuggling by sea.

\section{Conclusion.}

The conclusion of this article is that the Indonesian Navy (TNI AL) has the capacity to be structured to deal with the threat of special Nuclear, Biological and Chemical warfare. This can be used nationally to face the pandemic as it is today. The communication needs to be optimally established to be able to involve the Indonesian Navy more nationally, this is very possible because all the personnel of the Indonesian Navy have received sufficient supplies by being briefed when they first entered the TNI by the Puspek Nubika Kodiklatal's Surabaya.

In terms of resources, the Navy also has equipment that supports the handling of a pandemic, so the government in this case only needs to complete the equipment needed. The Navy's resources are structured in all regions of Indonesia so that this becomes an effective and efficient factor in handling pandemics.

In the disposition factor or attitude which is very important is related to authority, the Navy is very worthy of being given a further role in handling the pandemic nationally. Without the authority given to the Navy, it would be very unfortunate if it did not utilize the Navy's enormous potential and was very beneficial to the interests of the public at large.

On the bureaucratic structure factor that the Navy is part of the TNI force which by law has set the task of Military Operations Other than War (OMSP) is a very effective and efficient organization in speed of movement, history has proven the ability of the TNI in OMSP, always being in the line future in any event, especially in terms of handling disasters that have often occurred in Indonesia. The government must consciously see the potential of the TNI to further involve in the handling of a pandemic, there are many community interests that require the immediate presence of the TNI. Operational Procedure Standards and organizational fragmentation must be immediately created and implemented so that the benefit of the TNI can immediately become a pandemic handling solution.

\section{Acknowledge}

Our gratitude goes to the Indonesian researchers' community that is in informal group in the Whatsapp application, chaired by Dr. Supriadi for guidance and monitoring in writing this paper and thanks to the Indonesia defense University/Universitas Pertahanan Indonesia for providing the opportunity to carry out research and budget support in the publication of this article.

\section{Reference}

Agustino, L. (2008). Dasar-Dasar Kebijakan Publik. Alfabeta. Bandung, 2008.

BeritaSatu.com. (2020). Virus Corona Resmi Pandemik, Apa Bedanya dengan Epidemik? https://www.beritasatu.com/kesehatan/608209-virus-corona-resmi-pandemik-apa-bedanya-denganepidemik

Creswell, J. W., \& Poth, C. N. (2007). Qualitative inquiry \& research design; Choosing among five approach. In SAGE Publications, Inc. https://doi.org/10.1017/CBO9781107415324.004

Creswell, J. W., \& Poth, C. N. (2013). Qualitative Inquiry \& Research Design choosing among 5 approaches--4 ed.

Detik.com. (2020). Perjuangan Rakyat Semesta Perangi Wabah Corona. https://news.detik.com/kolom/d4965807/perjuangan-rakyat-semesta-perangi-wabah-corona

Edward III, G. C. (1980). Implementing Public Policy (T. A. \& M. University (ed.)). Congressional Quarterly Press.

Kompas.com. (2020). Jumlah Kasus Corona Global Capai 1 Juta, Berikut Kilas Balik Pandemi Covid-19. 
https://www.kompas.com/sains/read/2020/04/03/090856723/jumlah-kasus-corona-global-capai-1-jutaberikut-kilas-balik-pandemi-covid

Navylive, (2020). "USNS Mercy, USNS Comfort: 2020 COVID-19 Deployment", https://navylive.dodlive.mil/2020/03/26/usns-mercy-usns-comfort-2020-covid-19-deployment/

Nugroho, R. (2011). Public Policy; Dinamika Kebijakan, Analisis Kebijakan, Manajemen Kebijakan, Elekmedia Komputindo, Jakarta, 2011, hlm 636.

Pikiranrakyat.com. (2020). Update Virus Corona di Dunia 6 April 2020, Kasus Malaysia Tertinggi di Asia Tenggara. $\quad$ https://www.pikiran-rakyat.com/internasional/pr-01361323/update-virus-corona-di-dunia-6april-2020-kasus-malaysia-tertinggi-di-asia- tenggara,

Rothan, H. A., \& Byrareddy, S. N. (2020). The epidemiology and pathogenesis of coronavirus disease (COVID19) outbreak. In Journal of Autoimmunity. https://doi.org/10.1016/j.jaut.2020.102433

Suganthan, N. (2019). Covid-19. Jaffna Medical Journal. https://doi.org/10.4038/jmj.v31i2.72

Sugiyono. (2009). Metode Penelitian Kuantitatif, Kualitatif dan R\&D, Bandung:Alfabeta. Hal: 15. Bandung :Alfabeta, 2009.

Suhirwan, \& Prakoso, L. Y. (2019). Defense strategy at sea handling of Transnational Organized Crime (TNOC) in Nunukan Indonesia's national sea border. IOP Conference Series: Earth and Environmental Science, 339 (1). https://doi.org/10.1088/1755-1315/339/1/012043

Suhirwan, Prakoso, L. Y., \& Martani, W. R. (2020). Indonesian Navy as a Maritime Command Center Sea Defense Strategy. Public Policy and Administration Research, March. https://doi.org/10.7176/ppar/10-2-03

Undang-Undang RI NO 34 tahun 2004. (2004). Undang-undang Republik Indonesia No. 34 tahun 2004 Tentang Tentara Nasional Indonesia. 